\title{
The Incidence and Costs of Education-Occupation Mismatches in Canada: Evidence from Census Data
}

\author{
Najma R. Sharif ${ }^{1, *} \&$ Afshan Dar-Brodeur ${ }^{2}$ \\ ${ }^{1}$ Department of Economics, Saint Mary's University, Halifax B3H 3C3, Canada \\ ${ }^{2}$ Department of Economics, Carleton University, Ottawa, K1S 5B6, Canada \\ *Corresponding author: Department of Economics, Saint Mary's University, Halifax B3H \\ 3C3, Canada. Tel: 1-902-420-5616 E-mail: najma.sharif@smu.ca
}

Received: April 9, 2013

Accepted: May 6, 2013 Published: June 12, 2013

doi:10.5296/rae.v5i2.3505

URL: http://dx.doi.org/10.5296/rae.v5i2.3505

\begin{abstract}
The incidence of educational mismatch and the costs resulting thereof, are examined from the perspective of gender and nativity status, using Canadian census data. Mismatches arise when individuals are "over-educated" or "under-educated" relative to the normal levels of education in their occupation of employment. We first estimate a multinomial logit to assess the likelihood of educational mismatch, and examine the role gender, nativity status and, for foreign-born, language ability and length of residence in Canada, play in this regard. We then estimate earnings functions, generalized to model educational mismatches, to estimate the costs resulting from such mismatches, and to examine whether those costs vary across new and established foreign-born, and what role gender plays in this regard; also examined is the question of whether that penalty for foreign-born converges towards the same level as that of native-born, as the length of residence in Canada increases.
\end{abstract}

Keywords: educational mismatch; earnings penalty; foreign-born workers; Canada 


\section{Introduction}

This study examines the incidence of educational mismatch, and the impact, thereof, on earnings, from the perspective of gender and nativity status. Mismatches arise when individuals are "over-educated" or "under-educated" relative to the normal levels of education in their occupation of employment. As is argued in the literature on the subject, both types of educational mismatch impose an earnings penalty, and recent evidence for the US shows that this penalty can be large (Chiswick and Miller, 2008). There are many reasons for mismatched skills, regardless of gender and nativity status. Nonetheless, there are immigrant-specific and gender-specific factors that point to the likelihood that mismatches, especially involving over-education, could be relatively greater among women and foreign-born. While there is a substantial literature on the subject of mismatches, very little has been done to study the gender and country-of-origin implications of those mismatches for foreign-born. This study attempts to fill that gap.

The issue of mismatches raises two questions: first, what determines the likelihood that an individual would be over-educated or under-educated, or correctly matched; and, what roles do gender, nativity status and, for foreign-born, language ability and length of residence in Canada, play in this regard? Second, how do gender and nativity status interact in determining the size of the earnings penalty resulting from mismatches? In this paper, we first provide some evidence relating to the first question, and then turn to estimate the penalties associated with mismatches. With regard to the latter question, we examine whether the earning penalty differs among new and established foreign-born, and what role gender plays in this regard; also examined is the question of whether that penalty for foreign-born converges towards the same level as that of native-born men and women, as the length of residence in Canada increases. Both issues would shed light on the role gender and nativity status play in impeding the efficient use of labour in Canada, and in determining success in the labour market. These are relevant policy issues, firstly because they directly impact on the well-being of foreign-born by influencing their ability to integrate in the host country, and secondly because of the potential for negative impacts on economic growth, as noted by Ramos, Surinach, and Artids (2009).

One contribution of this paper is that it explicitly models and estimates the incidence of mismatch and how it varies by gender and nativity status. To our knowledge, the methodology adopted here has not been used before. While the issue of penalties that result from mismatch has recently been examined for Canada by Chiswick and Miller (2009a), these authors use a single cross-section to examine the issue of foreign-born convergence to native-born levels. This approach suffers from well-known difficulties; a second contribution of this paper is that we use a better alternative approach to this question. In examining these issues, we use the micro data files for individuals drawn from the 1991and 2001 Canadian censuses. The lack of equivalent data on key variables does not permit extending the analysis for the penalties from mismatch to the 2006 census. The incidence of over, under, and correctly-matched education by gender, across native-born and foreign-born groups, is examined by estimating a multinomial model that classifies individuals according to whether they are over-educated, under-educated, or correctly matched, while the estimation of penalties is based on the commonly-used earnings function, modified to incorporate the effects of educational mismatch, along the lines suggested by Hartog (2000). 


\section{Education-Occupation Mismatches: Some Conceptual Issues}

A worker would be matched to a particular occupation if he/she possessed the human capital required to perform with maximum efficiency in that occupation. There is, thus a "normal" or "reference" level of human capital associated with an occupation. Workers possessing this level of education are said to be correctly matched. In reality, many factors suggest why a mismatch would occur - see, for instance, Hartog (2000), McGuinness (2006), and Chiswick and Miller $(2008,2009 \mathrm{c})$. The following discussion in this section draws on this literature. First of all, mismatches arise because workers and employers possess imperfect information, and even with optimal search behaviour, workers end up in occupations where they are "over-educated' or "under-educated". Clearly, when the matching process is efficient, the educational distribution of workers in an occupation would be tightly concentrated around this "reference" skill level.

Mismatches also arise when the skills requirement in an occupation is upgraded over time; as a result, older workers appear to be under-educated, while younger hires appear to be over-educated, given the way mismatches are defined. The fact that the schooling premium on wages has increased in most industrial countries, also likely tends to raise the demand for education and a tendency for over-education. It is well recognized that a worker's skills constitute not just formal schooling and training, but unmeasured characteristics such as motivation, commitment, and innate ability, to name a few. It is, thus, likely that those with such desirable characteristics would be able to find employment in occupations where their schooling is less than the norm, and would thus appear as under-educated. At the same time, workers whom the market rates less favourably in terms of these characteristics would tend to gravitate towards lower occupations and appear to be over-educated.

The aforementioned factors are likely to be common for native-born and foreign-born males and females. However, the foreign-born experience in general, is likely to involve factors that are unique to them. As noted by Chiswick and Miller (2008, 2009b, 2009c), two important factors are the difficulty in transferring skills acquired in the home country, and the positive selectivity in migration. Skills transferability is limited because of greater imperfect information among foreign-born about host country labour markets and institutions, and language ability. As well, differences in technology and cultural norms lead to location-specific skills and practices that are not easily transferable at least in the short term. Occupational licensing or the non-recognition of foreign-born credentials restricts occupational mobility. This problem may also arise if risk averse employers are uncertain about the quality of skills acquired abroad. These factors suggest that foreign-born are more likely to be over-educated than equivalent native-born, as argued by Chiswick (1978). However, over time, greater familiarity with host country labour markets, greater language ability and the acquisition of new skills or the upgrading of old ones, will enable a better matching of education to jobs, so that over-education would fall. On the other hand, if discrimination pushes foreign-born into lower occupations, the skill transfer may not take place or take place only slowly, and over-education persists relative to the native-born. These effects might be more severe for non-traditional foreign-born because unfamiliar ethnic origins and/or the lack of language skills, might be seen as a signal of low-quality human capital. Available 
evidence supports the greater incidence of over-education of foreign-born (especially recent ones) relative to the native-born, and its decline over time -see, for instance Green, Kler and Leeves (2007) for Australia, Wald and Fang (2008) for Canada, Barret and Duffy (2009) for Ireland, and Chiswick and Miller (2008) for the US. However, evidence for Italy (Dell'Aringa and Pagani, 2010) and Spain (Fernandez and Ortega, 2008) does not support the decline of over-education among foreign-born over time.

It can also be argued that women are more likely to be over-educated than men. There is evidence that, despite changes in the past couple of decades or so, the occupational structure remains segregated by gender, with men more likely to be concentrated in managerial positions, while women continue to be overrepresented in secretarial, sales, teaching and nursing positions, as noted by the International Labour Office $(2004,7-8)$. There are a number of explanations for this segregation among otherwise similarly qualified men and women: from discrimination by employers, to social and cultural norms that emphasize women's role in the home, which limits their labour mobility, and often pushes them into part-time occupations, or into occupations that they are over-qualified for. Some note that occupational differences across individuals might also reflect differences in preferences. For instance, O'Connor (2001) argues that men and women differ in terms of their needs for things like affiliation, achievement, and power and self-actualisation, and go about meeting these needs in different ways. See (Kleinjans 2009) and Gneezy, Leonard and List (2009), for a different perspective. In reality, there are differences among women themselves, and the evidence from a number of countries provides no clear-cut evidence on whether women as whole are more likely than men to be over-educated - see, for instance, the meta analysis by Groot and Maassen van den Brink (2000).

Another source of mismatch specific to foreign-born is one that leads to under-education. This is due to the immigration selection process involved. Foreign-born are positively selected on the demand side if the immigration system rates potential foreign-born on their economic potential. On the supply side, most foreign-born are a self-selected group characterized by their desire for success, and are, thus, likely to be highly motivated and more inclined to success than others are. These traits also make them relatively mobile and less tied down my location-specific capital, factors which make them more flexible, allowing them to find occupations that match or exceed their skills and training (Chiswick 1978, 1999). Thus, one would expect that this positive selectivity of foreign-born would result in mismatches that are due to under-education.

\section{Empirical Models and Data}

In modeling the incidence of mismatch, we classify workers into three groups: those who are correctly matched in their occupation (coded as 1), those who are under-educated (coded as 2), and those who are over-educated (coded as 3). Over and under education are measured, as is common in the literature, relative to the "norm" for each occupation. The method for measuring mismatch is based on the "realized matches" approach, where the "norm" is the mean or modal level of education within each occupation. This approach has advantages over 
alternatives: it directly reflects the actual matching process in labour markets, as noted by Chiswick and Miller (2009c), and the requisite data are more readily available.

We treat the educational outcomes as coded above, as the result of a multinomial experiment, which can be explained by the following multinomial logit model:

$$
\ln \left(\partial_{i j} / \partial_{i m}\right)=\hat{\boldsymbol{a}}_{\boldsymbol{j}} \boldsymbol{x}_{\boldsymbol{i}}=\hat{a}_{j 0}+\dot{O} \hat{a}_{j k} X_{i k}+u_{i}
$$

where $\left(\pi_{i j} / \pi_{i m}\right)$ is the probability of individual $i$ being in category $j$, relative to the probability of being in some reference category $m$, the $\beta s$ are category-specific coefficients, the $X_{k}$ $(\mathrm{k}=1,2,3 . .,, \mathrm{K})$ are the $K$ explanatory variables, and $\mathrm{u}_{\mathrm{i}}$ is the random error term. Note that the coefficients in (1) are not easy to interpret; nor do their signs indicate the direction of impact on the probability of being in a given category. Rather, the signs of the coefficients indicate the direction of impact on the probability of being in category $j$ relative to the probability of being in the reference category $m$. It is possible to obtain an expression for the probability of being any category, from which the required marginal impacts can be obtained. Thus, the probability of being in category $\mathrm{j}$, can be obtained from the following:

$$
\pi_{\mathrm{ij}}=\exp \left(\beta_{\mathrm{j} 0}+\Sigma \beta_{\mathrm{jk}} \mathrm{X}_{\mathrm{ik}}\right) / \Sigma \exp \left(\beta_{\mathrm{j} 0}+\Sigma \beta_{\mathrm{jk}} \mathrm{X}_{\mathrm{ik}}\right)
$$

where, using the Theil normalization (that is, using the first category as the benchmark for comparison), we have $\beta_{10}=0$, and $\beta_{1 k}=0$ for all $k$. It can then be shown that the marginal impact of $X_{k}$ on the probability of being in any category $\mathrm{j}$, is given by:

$$
\partial \pi_{\mathrm{j}} / \partial \mathrm{X}_{\mathrm{k}}=\pi_{\mathrm{j}}\left(\beta_{\mathrm{jk}}-\beta^{*}\right)
$$

where $\beta^{*}=\sum \pi_{j} \beta_{j k} \quad$ for $k=1,2, \ldots, K$ and $j=1,2, \ldots . J$

Thus, we cannot associate $\beta_{j k}$ with the impact of the $k t h$ explanatory variable on the $j$ th outcome because of the presence of $\beta^{*}$, which depends also upon the average of all marginal effects that variable. It is evident that the signs of the $\beta_{j k}$ and that of the marginal effects as given by (3) can be different.

In discussing our findings below, our main focus will be on (2), which we use to estimate through simulation, the incidence of over-education, under-education, and being correctly matched, by gender and nativity status. Our explanatory variables, similar those used by Poot and Stillman (2010), control for actual education in years, age and its square, marital status, gender, geographical location, and foreign-born-specific variables reflecting length of residence in Canada, and fluency in English and/or French. Precise measures of these variables are given in Table 2. As an alternative to the age variable (and its square), we also looked at labour market experience (and its square). We measure experience as (age- 6- schooling), which is the widely-used measure in the empirical literature. We find that the results are strikingly similar; hence, our discussion of the results below is confined to the age variable only.

In order to examine the size of the penalties associated with over and under education, and to 
assess how they vary by gender and nativity status, and over time, we employ the ORU (from Over, Reference and Under education) methodology proposed by Hartog (2000). This involves estimating an earnings function modified to reflect ORU as follows:

$$
\ln W_{i}=\hat{a}_{0}+\hat{a}_{1} O E D_{i}+\hat{a}_{2} R E D_{i}+\hat{a}_{3} U E D_{i}+\ddot{a}^{\prime} \boldsymbol{X}_{\boldsymbol{i}}+u_{i}
$$

Here, $\mathrm{W}$ is the earnings of an individual, OED is the years of over-education, RED is the reference years of education, and UED is the years of under-education, and the vector $\boldsymbol{X}$ includes controls for other influences generally included in earnings functions, such as years of labor market experience (and its square), marital status, location, ethnicity, and variables specific to foreign-born, such as language ability, and length of residence in Canada. The precise measures of the variables used are given in Table 4 . Note that the actual years of education $E D=R E D+O E D-U E D$, and that only one of OED and UED can be positive for a given individual. The return to the reference level of schooling $\left(\hat{a}_{2}\right)$ is a return to having the extra year of education and being placed in an occupation where the education is normal - that is, it is the return to extra education when that education is correctly matched. Having more than this reference level of education raises the return, but only marginally - that is, $\hat{a}_{2}>$ $\hat{a}_{1}>0$. That is, mismatched additional education is really a penalty in that extra education, if correctly matched, would bring in a higher return. As Chiswick and Miller (2008, page 1323) note, a "cab driver with a BA earns more than the high school graduate cab driver, but the return on the extra four years of schooling is very low." Under-education also involves a penalty; this is measured by $\hat{a}_{3}<0$, and this means that an extra year of under-education lowers the overall return to schooling. The traditional approach to earnings implicitly assume that $\hat{a}_{1}=$ $\hat{a}_{3}=\left|\hat{a}_{3}\right|$.

The ORU equation (4) is first estimated using the 2001 census for native-born men and women, as well as for three groups of foreign-born (British, South Asians and Chinese) to capture ethnicity variations. These estimates allow us to examine the nature of the differences in the penalties resulting from mismatch by gender, nativity status and ethnicity, as well as to draw some initial conclusions about whether the penalties among foreign-born groups converge to those of the native-born. However, a comparison of arrival cohorts of different

vintage within a single cross-section (census) to infer convergence, suffers from the problem that the observed outcomes reflect not just convergence (or its absence), but also differences between these cohorts. This approach was used in a recent paper by Chiswick and Miller (2009a). To deal with this problem, we use the "synthetic" cohorts method in that we track he same cohort through the 1991 and 2001 censuses. Although the individuals in this cohort are not the same at each census, they are samples drawn from the same population (that is, all those who arrived in the same period). We consider the 1986-90 cohort of foreign-born when they were new to Canada at the time of the 1991 census, and examine the evolution of educational mismatch and the earnings penalty for this group over the next 10 years.

We confine our attention to workers in the 25-64 age group, who worked full time (that is, at least 40 hours a week). The foreign-born samples are the full samples of individuals that satisfy these restrictions, while the native-born samples are 25-30 percent random samples drawn from all full-time, native-born workers in the 25-64 age group. These restrictions are common 
in the literature - see, for instance, Baker and Benjamin (1994), Ferrer and Riddell (2008), and Chiswick and Miller (2009a). The reference level of education (in each census year) is the mean education level (in years) of native-born men and women in each occupation, which is also common to most studies that use the realized matches approach. We use the occupational classification in the Canadian census, which has 25 categories in the 2001 census, and 16 in 1991 census. Table 1 presents descriptive summary statistics on the incidence of mismatch by gender and nativity.

Table 1: Mean Educational Mismatches (2001 Census)

\begin{tabular}{|c|c|c|c|}
\hline & $\begin{array}{c}\text { Actual education } \\
\text { (years) }\end{array}$ & $\begin{array}{c}\text { Over-Education } \\
\text { (years) }\end{array}$ & $\begin{array}{c}\text { Under-Education } \\
\text { (years) }\end{array}$ \\
\hline \multicolumn{4}{|l|}{ Native-Born } \\
\hline Women & $\begin{array}{l}13.94 \\
(2.6)\end{array}$ & $\begin{array}{l}0.84 \\
(1.2)\end{array}$ & $\begin{array}{l}0.96 \\
(1.4)\end{array}$ \\
\hline Men & $\begin{array}{l}13.62 \\
(2.9)\end{array}$ & $\begin{array}{c}1.0 \\
(1.3)\end{array}$ & $\begin{array}{l}0.91 \\
(1.6)\end{array}$ \\
\hline \multicolumn{4}{|l|}{ Foreign-Born } \\
\hline Women & $\begin{array}{l}13.75 \\
(3.4)\end{array}$ & $\begin{array}{l}1.13 \\
(1.4)\end{array}$ & $\begin{array}{l}1.11 \\
(2.1)\end{array}$ \\
\hline $\begin{array}{l}\text { New arrivals } \\
(1996-2000)\end{array}$ & $\begin{array}{l}14.50 \\
(3.4)\end{array}$ & $\begin{array}{l}1.62 \\
(1.6)\end{array}$ & $\begin{array}{l}0.80 \\
(1.9)\end{array}$ \\
\hline $\begin{array}{l}\text { Recent arrivals } \\
\text { (1991-1995) }\end{array}$ & $\begin{array}{l}13.84 \\
(3.4)\end{array}$ & $\begin{array}{l}1.40 \\
(1.6)\end{array}$ & $\begin{array}{l}0.91 \\
(2.0)\end{array}$ \\
\hline $\begin{array}{l}\text { Old arrivals } \\
(1986-1990)\end{array}$ & $\begin{array}{l}13.86 \\
(3.4)\end{array}$ & $\begin{array}{l}1.24 \\
(1.5)\end{array}$ & $\begin{array}{l}0.97 \\
(2.1)\end{array}$ \\
\hline Men & $\begin{array}{l}13.93 \\
(3.6)\end{array}$ & $\begin{array}{l}1.34 \\
(1.6)\end{array}$ & $\begin{array}{l}1.0 \\
(2.1)\end{array}$ \\
\hline $\begin{array}{l}\text { New arrivals } \\
(1996-2000)\end{array}$ & $\begin{array}{l}14.96 \\
(3.8)\end{array}$ & $\begin{array}{l}1.86 \\
(1.8)\end{array}$ & $\begin{array}{l}0.61 \\
(1.8)\end{array}$ \\
\hline Recent arrivals & 13.99 & 1.44 & 0.87 \\
\hline (1991-1995) & $(3.5)$ & (1.7) & $(2.0)$ \\
\hline $\begin{array}{l}\text { Old arrivals } \\
(1986-1990)\end{array}$ & $\begin{array}{c}13.89 \\
(3.6)\end{array}$ & $\begin{array}{l}1.45 \\
(1.70\end{array}$ & $\begin{array}{l}0.97 \\
(2.1)\end{array}$ \\
\hline $\begin{array}{l}\text { Country/Regio } \\
\text { Women }\end{array}$ & & & \\
\hline UK\&US & $\begin{array}{l}14.50 \\
(2.4)\end{array}$ & $\begin{array}{l}0.99 \\
(1.3)\end{array}$ & $\begin{array}{l}0.71 \\
(1.2)\end{array}$ \\
\hline Europe & $\begin{array}{l}13.12 \\
(3.9)\end{array}$ & $\begin{array}{c}1.0 \\
(1.4)\end{array}$ & $\begin{array}{l}1.57 \\
(2.5)\end{array}$ \\
\hline South Asia & $\begin{array}{l}13.86 \\
(3.3)\end{array}$ & $\begin{array}{l}1.39 \\
(1.6)\end{array}$ & $\begin{array}{l}0.90 \\
(1.9)\end{array}$ \\
\hline S-E Asia & $\begin{array}{l}13.74 \\
(3.6)\end{array}$ & $\begin{array}{l}1.27 \\
(1.5) \\
\end{array}$ & $\begin{array}{c}1.10 \\
(2.23)\end{array}$ \\
\hline
\end{tabular}




\section{Men}

UK\&US

14.86

1.36

0.55

Europe

13.11

(1.5)

1.13

1.49

South Asia

14.06

S-E Asia

14.06

(3.6)

Notes: Numbers in parentheses are standard deviations; the mean reference years of education is 13.75 years, with a standard deviation of 2.79 .

\section{Discussion of the Results}

We first discuss the results pertaining to the incidence of educational mismatch by gender and nativity status, and then turn to the penalties associated with mismatches.

\subsection{The Incidence of Educational Mismatch: Findings from the Multinomial Logit Model}

Table 2 provides estimates of the logit models for native-born and foreign-born workers from 2001 census data. The estimated coefficients measure the effect of the corresponding explanatory variable on the probability of being over-educated (under-educated), relative to the probability of being correctly matched. For both the native-born and foreign-born, it is evident that better educated individuals are more likely to be over-educated and less likely to be under-educated relative to being correctly matched. These coefficients are highly significant even at the 1 percent level. Turning to the role of gender, women are more likely to over-educated and less likely to be under-educated (relative to being correctly matched) compared to men among both foreign-born and the native-born. However, the gender differences are significant only at the 10 percent level for the native-born. For the foreign-born, the impact on over-education is highly significant, but only at the 10 percent level for under-education; as well, those who know at least one official language, are much less likely to be over-educated and much more likely to be under-educated, both relative to the likelihood of being correctly matched, than those who do not know at least one official language. Furthermore, length of residence matters in that newer foreign-born cohorts (those that came after 1986), are much more likely to be over-educated than established foreign-born (those who came prior to 1986), again relative to the probability of being correctly matched. The reverse is found for under-education. 
Table 2: Multinomial Logit Estimates of Educational Mismatch (2001 Census)

\begin{tabular}{|c|c|c|c|c|}
\hline & \multicolumn{2}{|c|}{ Native-Born } & \multicolumn{2}{|c|}{ Foreign-born } \\
\hline & $\begin{array}{c}\text { Probability of } \\
\text { Under-Education }^{\mathrm{a}}\end{array}$ & $\begin{array}{c}\text { Probability of } \\
\text { Over-Education }^{\mathrm{a}}\end{array}$ & $\begin{array}{c}\text { Probability of } \\
\text { Under-Education }^{\mathrm{a}}\end{array}$ & $\begin{array}{c}\text { Probability of } \\
\text { Over-Education }^{\text {a }}\end{array}$ \\
\hline \multirow[t]{2}{*}{ Constant } & 15.51 & -8.11 & 14.72 & -9.262 \\
\hline & $(44.41)$ & $(-30.37)$ & $(34.67)$ & $(-31.85)$ \\
\hline Education & -1.289 & 0.5906 & -1.302 & 0.6191 \\
\hline (years) & $(-80.80)$ & $(71.38)$ & $(-72.83)$ & $(76.30)$ \\
\hline Age & $-0.0134^{*}$ & -0.0478 & $0.0282 *$ & $-2.61 \times 10^{-3} *$ \\
\hline (years) & $(-0.960)$ & $(-4.091)$ & $(1.758)$ & $(-0.231)$ \\
\hline Age-squared & $3.94 \times 10^{-4}$ & $4.84 \times 10^{-4}$ & $-1.28 \times 10^{-4} *$ & $8.01 \times 10^{-5} *$ \\
\hline (years squared) & $(2.382)$ & $(3.423)$ & $(-0.712)$ & $(0.617)$ \\
\hline \multirow[t]{2}{*}{ CMA resident } & 0.2268 & -0.0734 & $-0.0425^{*}$ & 0.1186 \\
\hline & $(7.22)$ & $(-2.653)$ & $(-0.749)$ & $(2.689)$ \\
\hline \multirow[t]{2}{*}{ Married } & 0.1550 & -0.1918 & 0.1077 & $-0.0380^{*}$ \\
\hline & $(4.489)$ & $(-6.801)$ & $(2.51)$ & $(-1.261)$ \\
\hline \multirow[t]{2}{*}{ Quebec } & 0.479105 & 0.3990 & 0.5988 & 0.4651 \\
\hline & $(9.390)$ & $(9.202)$ & $(8.302)$ & $(9.403)$ \\
\hline \multirow[t]{2}{*}{ Ontario } & $0.0118^{*}$ & $-0.0381^{*}$ & 0.1098 & 0.1784 \\
\hline & $(0.012)$ & $(-0.915)$ & $(2.833)$ & $(5.200)$ \\
\hline \multirow[t]{2}{*}{ Prairie } & $0.0425 *$ & -0.1232 & $-0.0214^{*}$ & $0.0294 *$ \\
\hline & $(0.815)$ & $(-2.632)$ & $(-0.334)$ & $(0.626)$ \\
\hline \multirow[t]{2}{*}{ Gender } & $-0.0013^{*}$ & $0.0278^{*}$ & $-0.0631 * *$ & 0.1404 \\
\hline & $(-0.042)$ & $(1.103)$ & $(-1.783)$ & $(5.529)$ \\
\hline \multirow[t]{2}{*}{ Language } & $\mathrm{Ni}$ & $\mathrm{Ni}$ & 0.3619 & -0.7277 \\
\hline & & & $(3.073)$ & $(-5.010)$ \\
\hline \multirow[t]{2}{*}{ 1986-1990 cohort } & & & -0.2164 & 0.4631 \\
\hline & $\mathrm{Ni}$ & $\mathrm{Ni}$ & $(-4.049)$ & $(12.341)$ \\
\hline \multirow[t]{2}{*}{ 1991-1995 cohort } & & & -0.3360 & 0.5389 \\
\hline & $\mathrm{Ni}$ & $\mathrm{Ni}$ & $(-6.386)$ & (14.54) \\
\hline \multirow[t]{2}{*}{ 1996-2000 cohort } & & & -0.2085 & 0.5531 \\
\hline & $\mathrm{Ni}$ & $\mathrm{Ni}$ & $(-2.984)$ & $(13.10)$ \\
\hline Log likelihood & \multicolumn{2}{|c|}{43305} & \multicolumn{2}{|c|}{47085} \\
\hline Sample size & \multicolumn{2}{|c|}{49010} & \multicolumn{2}{|c|}{47218} \\
\hline
\end{tabular}

Notes: ${ }^{a}$ Each probability in this column is relative to the probability of being correctly matched; numbers in parentheses are $\mathrm{t}$ ratios; $\mathrm{Ni}=$ variable not included; ** significant at the 10 percent level; * not significant at the 10 percent level; all other coefficients are significant at the 5 percent level or less. $\mathrm{CMA}=1$ if resident of a census metropolitan area (zero if not); Marr=1 if married (zero if not); Quebec=1, Onatrio1, Prairie=1, if individual is resident of that province/region (default region British Columbia); Gender $=1$ if female (zero if not); for foreign-born only, Language $=1$ if individual knows at least one official language (zero if not); each foreign-born arrival cohort is each equal to 1 if individual entered Canada in that period (default is anyone arriving prior to 1986). 
As noted earlier, the direction of the impact of explanatory variables on the absolute (as opposed to relative) probability of being over-educated, under-educated or correctly matched, cannot be ascertained from the logit model coefficients. For this, we need to obtain the marginal effects as given by equation (3). Table 3 below reports the signs of these effects.

Table 3: Signs of Marginal Effects (Equation 3)

\begin{tabular}{lcccccc}
\hline \multicolumn{1}{c}{$\begin{array}{c}\text { Explanatory } \\
\text { Variables }\end{array}$} & Matched & $\begin{array}{c}\text { Under-ed } \\
\text { ucated }\end{array}$ & $\begin{array}{c}\text { Over-edu } \\
\text { cated }\end{array}$ & Matched & $\begin{array}{c}\text { Under-e } \\
\text { ducated }\end{array}$ & $\begin{array}{c}\text { Over-edu } \\
\text { cated }\end{array}$ \\
\hline Education & + & - & + & - & - & + \\
Gender & - & - & + & - & - & + \\
Language & $\mathrm{Ni}$ & $\mathrm{Ni}$ & $\mathrm{Ni}$ & + & + & - \\
Length of & $\mathrm{Ni}$ & $\mathrm{Ni}$ & $\mathrm{Ni}$ & - & - & + \\
residence & & & & & & \\
\hline
\end{tabular}

Notes: The gender effect is the impact of being female rather than male; the language effect is the impact of knowing at least one official language rather than none; the effect of length of residence impact is the impact of being a new foreign-born compared to an established foreign-born - a new foreign-born is one belonging to the 1996-2000 cohort, while an established foreign-born is one that came prior to 1986. All marginal effects are calculated using equation (3); $\mathrm{Ni}=$ variable not included.

As can be seen from the table, women are more likely than men to be over-educated, and less likely to be correctly matched or under-educated, regardless of nativity status. At the same time, better educated individuals, native or foreign-born, are also more likely to be over-educated and less likely to be under-educated. However, while greater education makes it more likely that native-born will be correctly matched, the opposite is true for foreign-born. This may reflect problems of skills transfer, blocked mobility or discrimination for the foreign-born. Among the foreign-born, new foreign-born (those who came during 1996-2000) are more likely to be over-educated, and less likely to be under-educated or correctly matched compared to established foreign-born (those who came prior to 1986). As well, those who know at least one official language are less likely to be over-educated, and more likely to be under-educated or correctly matched.

We next assess the differences in the incidence of correct matching and over and under education by gender and nativity status, and by length of residence for foreign-born men and women. This is done through simulation, using the estimates of equation (2). Specifically, we simulate the probability of being overeducated, undereducated, and correctly matched, for native-born and foreign-born men and women, who are otherwise equivalent in terms of age, education, location, and marital status. As our base or comparison group of individuals, we consider male and female individuals who possess the following common characteristics: all are married residents of Ontario, and live in a CMA (census metropolitan area), are 45 years of age, and have 14 years of education. For the foreign-born, we additionally consider two cohorts - established foreign-born who came prior to 1986 and new foreign-born who came between 1996-2000, and consider those who knew at least one official language. 
To emphasize gender and nativity differences, we present in Table 4, two types of relative probabilities - one that gives a gender perspective, and one that highlights the gaps between the native-born and foreign-born. The gender perspective involves looking at the ratio of female to male probabilities among the native-born, and foreign-born separately. These are presented in the first three columns of Table 4. They show that native-born male and females are approximately equally likely to be over or under-educated or correctly matched, as the ratio of probabilities is close to unity. For the foreign-born, on the other hand, for both those who are new to the country (arrived within the last 5 years), or have been in the country at least 15 years ago, women are clearly more likely to be over-educated and less likely to be under-educated than men. The gender gap in the probability of being correctly matched for the foreign-born is smaller by about 3-5 percentage points.

Table 4: Relative Probabilities of Educational Mismatch (2001 Census)

\begin{tabular}{|c|c|c|c|c|c|c|c|}
\hline & \multicolumn{3}{|c|}{$\begin{array}{l}\text { Ratio of Female to Male } \\
\text { Probabilities }\end{array}$} & \multicolumn{4}{|c|}{$\begin{array}{l}\text { Ratio of Foreign-Born to Native-Born } \\
\text { Probabilities }\end{array}$} \\
\hline & \multirow{2}{*}{$\begin{array}{l}\text { Native- } \\
\text { Born }\end{array}$} & \multicolumn{2}{|c|}{ Foreign-Born } & \multicolumn{2}{|c|}{ Women } & \multicolumn{2}{|c|}{ Men } \\
\hline & & New & Old & New & Old & New & Old \\
\hline Over & & & & & & & \\
\hline Education & 1.03 & 1.10 & 1.12 & 2.02 & 1.38 & 1.89 & 1.26 \\
\hline $\begin{array}{l}\text { Under } \\
\text { Education }\end{array}$ & 0.99 & 0.89 & 0.91 & 0.58 & 0.85 & 0.65 & 0.93 \\
\hline $\begin{array}{l}\text { Reference } \\
\text { Education }\end{array}$ & 0.99 & 0.95 & 0.97 & 0.78 & 0.92 & 0.81 & 0.94 \\
\hline
\end{tabular}

Notes: Each row entry is a relative probability (female to male in the first three columns, and foreign-born to native-born in the last four columns), corresponding to each type of education indicated in the first column. New foreign-born are those who entered Canada between 1996-2000, while old foreign-born are those who entered before 1986.

The last four columns of Table 4 show the foreign-born to native-born probabilities for men and women separately. It can be see that, among men, new foreign-born are about 89 percent more likely to be over-educated, 35 percent less likely to be under-educated, and about 19 percent less likely to be correctly matched than the native-born. On the other hand, foreign-born men who have been in the country at least 15 years are much closer to the native-born in each case. This pattern is more or less replicated among women, but the gap between foreign-born and native-born women is larger than that for men. Thus, even foreign-born women who have been in Canada at least 15 years are 38 percent more likely and 15 percent less likely than native-born women to be over-educated and under-educated respectively. These findings are, in general, in accordance with prior expectations - the greater incidence of over-education among women, especially foreign-born, the lower under-education of foreign-born due to positive selection, a decline in over-education and an increase in under-education, along with better job matching, of foreign-born the longer they have been in Canada. 


\subsection{ORU Regression Results: The Returns to Education}

Tables 5 and 6 summarize the returns to actual, reference, over and under education by gender and nativity status, as estimated from the ORU model (4), using 2001 census data. We also present the basic results obtained by estimating a traditional earnings function. Since our interest is primarily in the payoff to the three types of education, we present results only for these variables. The estimates of the traditional earnings function show that the return to actual education is 7 percent for native-born men and 5.7 percent for foreign-born men, a difference of about 1.3 percentage points. The native-born female return is higher at 10.2 percent compared to 6.2 percent for foreign-born females, implying a much wider gap than seen for males. All estimated returns are highly significant at even the 1 percent level.

Turning next to the ORU model estimates, it can be seen that among males, the native-born return to reference education is 13.1 percent, which is about 6 percentage points greater than the return to actual education for this group. This is not surprising since this substantially greater matched return reflects the benefit from an extra year of education plus the return accruing by placing that year in the correct occupation. For foreign-born men, the gap between the return to reference education and actual education is even larger at about 10 percentage points. Thus, job matching appears to be more important for foreign-born men.

Table 5: Estimated Conventional and ORU Earnings Functions for Men ${ }^{\mathrm{a}}$ (2001 Census)

\begin{tabular}{lllll}
\hline \multirow{2}{*}{ Variable } & \multicolumn{2}{l}{ Native-Born Men } & \multicolumn{2}{l}{ Foreign-Born } \\
& $\begin{array}{l}\text { Conventional } \\
\text { Model }\end{array}$ & $\begin{array}{l}\text { ORU } \\
\text { Model }\end{array}$ & $\begin{array}{l}\text { Conventional } \\
\text { Model }\end{array}$ & $\begin{array}{l}\text { ORU } \\
\text { Model }\end{array}$ \\
\hline Actual Education & 0.0700 & Not & 0.0574 & Not included \\
& $(34.48)$ & included & $(30.59)$ & \\
Reference & $\mathrm{Ni}$ & 0.1313 & $\mathrm{Ni}$ & 0.1569 \\
Education & & $(38.96)$ & & $(42.93)$ \\
Over-education & $\mathrm{Ni}$ & 0.0476 & & 0.0430 \\
& & $(11.11)$ & $\mathrm{Ni}$ & $(11.84)$ \\
Under-education & $\mathrm{Ni}$ & -0.0477 & & -0.0216 \\
& & $(-11.28)$ & $\mathrm{Ni}$ & $(-5.96)$ \\
Other Controls & $\mathrm{Yes}$ & $\mathrm{Yes}$ & $\mathrm{Yes}$ & Yes \\
Sample Size & 28,250 & 28,250 & 27,444 & 27,444 \\
R-squared & 0.11 & 0.12 & 0.11 & 0.14 \\
F-statistic & 374.6 & 356.8 & 285.6 & 317.6 \\
\hline
\end{tabular}

Notes: ${ }^{a}$ Numbers in parentheses are t-ratios (based on heteroscedasticity-consistent standard errors).All coefficients are statistically significant at the 5 percent level or less, unless indicated otherwise. ${ }^{b}$ The reference or usual level of education is the mean level of education in each occupation. ${ }^{\mathrm{c}}$ Labour market experience=age-schooling- 6 , and its square; log of weeks worked; binary variables equal to 1 if the individual is female, married, lives in a CMA in Ontario, or Quebec, or the prairie provinces; for foreign-born, also included are years since immigration (and its square); binary variables equal to 1 if the individual knows at least one official language. 
Table 6: Estimated Conventional and ORU Earnings Functions for Women ${ }^{\mathrm{a}}$ (2001 Census)

\begin{tabular}{|c|c|c|c|c|}
\hline \multirow{3}{*}{ Variable } & \multicolumn{2}{|c|}{ Native-Born Women } & \multicolumn{2}{|c|}{ Foreign-Born Women } \\
\hline & Conventional & ORU & Conventional & ORU \\
\hline & Model & Model & Model & Model \\
\hline \multirow[t]{2}{*}{ Actual Education } & 0.1023 & $\mathrm{Ni}$ & 0.0616 & $\mathrm{Ni}$ \\
\hline & (44.29) & & $(26.32)$ & \\
\hline Reference & $\mathrm{Ni}$ & 0.1854 & $\mathrm{Ni}$ & 0.1644 \\
\hline Education $^{\mathrm{b}}$ & & $(48.87)$ & & $(36.03)$ \\
\hline \multirow[t]{2}{*}{ Over-education } & $\mathrm{Ni}$ & 0.0719 & & 0.0448 \\
\hline & & $(14.82)$ & $\mathrm{Ni}$ & $(9.02)$ \\
\hline \multirow[t]{2}{*}{ Under-education } & $\mathrm{Ni}$ & -0.0663 & $\mathrm{Ni}$ & -0.0275 \\
\hline & & $(-11.27)$ & & $(-6.64)$ \\
\hline Other Controls $^{\mathrm{c}}$ & Yes & Yes & Yes & Yes \\
\hline Sample Size & 20,760 & 20,760 & 20,744 & 20,744 \\
\hline R-squared & 0.14 & 0.18 & 0.11 & 0.14 \\
\hline F-statistic & 390.4 & 400.2 & 214.6 & 241.2 \\
\hline
\end{tabular}

Notes: See notes to Table 5

These findings are in line with those of Chiswick and Miller (2009a), who find that the return to reference education is 12.5 percent for native-born men and 15.7 percent for foreign-born men, while the corresponding estimates (available only for men) are 14.9 percent and 13.7 percent in the US (Chiswick and Miller, 2008), and 15.2 percent for native and foreign born in Australia (Chiswick and Miller, 2009d). For women, the native-born return to matched education is 18.5 percent which is about 8 percentage points higher than the actual return, while for the foreign-born the matched return is 16.4 percent compared to 6.2 percent for actual education. The higher returns to reference education for males compared to females was also found in a number of other studies, as discussed in Hartog(2000). These numbers suggest that job matching is even more important for women than for men in Canada.

The tables also show that the returns to over-education are low, only 4.8 percent for native-born males and 4.3 percent for foreign-born males; these are only 37 percent and 27 percent respectively of matched returns for these groups. Among females, over-education commands a higher return of 7.2 percent for native-born females, compared to 4.5 percent for foreign-born women. These two returns are also, respectively, just 39 percent and 27 percent of their respective matched returns. Thus, the labour market imposes a large earnings penalty of over-education for both the foreign-born and native-born, regardless of gender. Nonetheless, foreign-born women and men pay a higher penalty in that their returns to over-education relative to their matched returns are much smaller than the corresponding returns for native-born women and men. The Chiswick and Miller studies for the US and Australia noted in the previous paragraph point to similar returns to over-education - in the 5-6 percent range for the native-born and 3.5-5 percent range for foreign-born.

Finally, the penalty of under-education is quite similar for foreign-born men and women (in the 2.2-2.8 percent range), while the corresponding estimates for the native-born range from 6.6 
percent for women to 4.8 percent for men. The former amounts to about 14-17 percent of the matched return for foreign-born men and women, compared to 35-37 percent for native-born men and women. As noted in the previous section, the lower penalty for under-educated foreign-born likely reflects their positive selectivity, both from the supply side (those who are migrate likely possess beneficial unobserved characteristics), and the demand side (economic migrants who are rated for their skills). Note also that the gender difference in the penalty from under-education is relatively minor among foreign-born, compared to the native-born. This pattern is consistent with the Chiswick and Miller (2008, 2009a, 2009d) findings for the US, Canada, and Australia.

\subsection{Ethnic Variations}

Table 7 presents the estimates for the returns to the three types of education for three foreign-born groups of men and women - British foreign-born, South Asian foreign-born, and Chinese foreign-born. For all categories of education, British gender differences are qualitatively similar to native-born gender differences - the returns to actual, reference and over-education are all higher for women compared to men, as is the penalty from under-education. For the South Asian and Chinese foreign-born, who can be considered "non-traditional" immigrants, the pattern is completely reversed, albeit not always by substantial amounts.

Table 7: Estimates of ORU Earnings Functions by Foreign-born Group (2001 Census) ${ }^{\mathrm{a}}$

\begin{tabular}{lllllll}
\hline & \multicolumn{2}{l}{ Foreign-Born Women } & \multicolumn{3}{l}{ Foreign-Born Men } \\
& British & $\begin{array}{l}\text { South } \\
\text { Asian }\end{array}$ & Chinese & British & $\begin{array}{l}\text { South } \\
\text { Asian }\end{array}$ & Chinese \\
\hline Actual & 0.0794 & 0.0519 & 0.0526 & 0.0632 & 0.0690 & 0.0757 \\
Education & $(10.16)$ & $(6.94)$ & $(7.07)$ & $(10.50)$ & $(10.54)$ & $(101.35)$ \\
Reference $^{\text {Education }}{ }^{\text {b }}$ & 0.1767 & 0.1429 & 0.1672 & 0.1433 & 0.1463 & 0.1794 \\
Over-education & $(16.20)$ & $(8.94)$ & $(10.35)$ & $(15.14)$ & $(11.91)$ & $(13.71)$ \\
& 0.0507 & 0.0448 & 0.0324 & 0.0388 & 0.0605 & 0.0467 \\
& $(2.63)$ & $(2.92)$ & $(2.24)$ & $(4.07)$ & $(5.80)$ & $(3.85)$ \\
Under-education $^{c}$ & $(-2.61)$ & $(-1.26)^{*}$ & $(-1.79)^{* *}$ & $(-2.47)$ & $(-1.83)^{* *}$ & $(-3.59)$ \\
Other Controls & Yes & Yes & Yes & Yes & Yes & Yes \\
Sample Size & 2292 & 1784 & 2140 & 3243 & 2951 & 2544 \\
R-squared & 0.13 & 0.13 & 0.20 & 0.13 & 0.13 & 0.23 \\
F-statistic & 26.9 & 18.7 & 37.6 & 38.7 & 30.6 & 55.1 \\
\hline
\end{tabular}

Notes: See Notes to Table 5; * not significant at the 10 percent level; ** significant at the 10 percent level; all other coefficients are significant at the 5 percent level or less; the first row of numbers is the return to actual education, obtained from traditional earnings functions regressions (not reported here).

Labour markets reward over-education poorly for the three foreign-born groups as well; the return to over-education, relative to the return to reference education, ranges from a low 19 percent for Chinese women to a high of 42 percent for South Asian men. As with the aggregate 
results, these numbers imply that labour market matching is important for earnings for all groups. It is especially important for Chinese men and women. Gender differences are also important, with over-education rewarding Chinese and South Asian men much more significantly (compared to their female counterparts), while the reverse is true for the British. By the same token, the penalty for under-education is significantly larger for Chinese and South Asian men compared to their female counterparts, although the opposite holds for the British.

\subsection{Intertemporal Comparisons: Length of Residence Effects}

How do the various returns to education of the foreign-born behave over time, as skills transfer to the host country becomes more complete, and they have the opportunity to improve job matches? To assess this question we estimated the ORU model for the 1986-90 arrival cohort at the 1991 census when it was "new" to Canada and then again ten years later at the 2001 census, when this cohort had been in the country 10-15 years. To examine convergence, we look at the changes in returns of the 1986-1990 foreign-born cohort relative to native-born returns between 1991 and 2001, for men and women separately. These relative returns are reported in Table 8, while the ORU equations by census for the 1986-1990 cohort are given in Table 9. We confine our discussion to Table 8.

It can be seen that, as far as women are concerned, the matched return to education for the foreign-born, relative to those of the native-born, rises from 87 percent in 1991, when they are new to Canada, to 95 percent in 2001, pointing to convergence. A narrowing of the foreign-born-native-born gap in the penalty to under-education is also observed over this period, but convergence is far from complete as the foreign-born penalty is still only 53 percent of the native-born penalty after 10 years. The returns to over-education, on the other hand, point to divergence, as the ratio of foreign-born to native-born returns for women falls from 79 percent to 70 percent over this 10 -year period.

Table 8: Returns (\%) to Education 1986-1990 Arrival Cohort and Native-Born

\begin{tabular}{lllll}
\hline & \multicolumn{4}{l}{ Ratio of Foreign-Born to Native-Born Returns } \\
& Women & \multicolumn{4}{l}{ Men } \\
& 1991 & 2001 & 1991 & 2001 \\
& Census & Census & Census & Census \\
\hline Reference Education & 0.87 & 0.95 & 1.14 & 1.19 \\
Over-education & 0.79 & 0.70 & 0.75 & 0.90 \\
Under-education & 0.28 & 0.53 & 0.11 & 0.45 \\
\hline
\end{tabular}

Notes: Foreign-born returns were obtained from ORU estimates for the 1986-1990 cohort in 1991 and 2001. These are reported in Table 9 below. The native-born returns for 2001 are taken from Tables 5 and 6, while those for 1991 are based on ORU regressions using 1991 census data (not reported here).

As far as men are concerned, the foreign-born-native-born gap in the penalty to under-education show similar trends to those observed for women. However, unlike women, new foreign-born born returns to over-education for men rise relative to those of the native-born. Convergence is partial in that those returns are still only 90 percent of native-born 
returns after 10 years. As well, it is interesting to note that 1986-1990 cohort's matched returns are actually higher than those of the native-born, both in 1991 and 1002, and there is no evidence of convergence.

Table 9: Estimates ORU Earnings Functions by Census (1986-1990 Arrival Cohort) ${ }^{\mathrm{a}}$

\begin{tabular}{lllll}
\hline & \multicolumn{2}{l}{ Foreign-Born Women } & \multicolumn{2}{l}{ Foreign-Born Men } \\
& 1991 Census & 2001 Census & 1991 Census & 2001 Census \\
\hline Reference & 0.1456 & 0.1754 & 0.1273 & 0.1568 \\
Education $^{\text {b }}$ & $(13.02)$ & $(13.49)$ & $(13.81)$ & $(15.45)$ \\
Over-education & 0.0398 & 0.0500 & 0.0457 & 0.0511 \\
& $(3.49)$ & $(4.60)$ & $(4.59)$ & $(5.91)$ \\
Under-education & -0.0146 & -0.0350 & -0.006 & -0.0210 \\
& $(-10.04)^{*}$ & $(-3.03)$ & $(-0.05)^{*}$ & $(-3.14)$ \\
Other Controls & Yes & Yes & Yes & Yes \\
Sample Size & 2136 & 3087 & 3002 & 3831 \\
R-squared & 0.17 & 0.10 & 0.14 & 0.11 \\
F-statistic & 31.0 & 24.7 & 33.3 & 34.5 \\
\hline
\end{tabular}

Notes: See Notes to Table 5; * not significant at 10 percent level; all other coefficients are significant at the 5 percent level or less.

\section{Conclusion}

This paper examined the incidence of mismatch between a person's education level and that required by the occupation that person is employed in, and the resulting impact on earnings, from the perspective of gender and nativity status in Canada. Evidence from the 2001 census shows that native-born male and females are approximately equally likely to be over or under-educated or correctly matched, but among new or established foreign-born, women are clearly more likely to be over-educated and less likely to be under-educated than men. On the role of nativity status, among men, new foreign-born are about 89 percent more likely to be over-educated, 35 percent less likely to be under-educated, and about 20 percent less likely to be correctly matched than the native-born. Established immigrant men, on the other hand, are much closer to the native-born in each case. This pattern is more or less replicated among women. These findings are, in general, in accordance with prior expectations.

We also find that educational mismatch imposes large penalties on all groups by depressing the returns to actual education relative to what they those returns would be from correct matching. However, there are large differences by nativity status, with educational matching being much more important for the foreign-born, but gender differences are relatively small.

Our findings for the penalties from under-education also point to the relatively smaller role played by gender as compared to nativity status. This likely reflects the positive selectivity of immigrants.

We find some clear ethnic and gender differences among the foreign born. Thus, while British 
immigrants show slight gender differences in the penalties from educational mismatch, those differences are quite sharp among South Asian and Chinese immigrants. Typically, relative to matched returns, the return to over-education for Chinese and South Asian men are much higher than those for the corresponding women. Within each gender, there are also large differences in penalties. Thus, Chinese and South Asian women earn much less relative to their matched returns compared to British women.

We find that the returns to correctly matched education show convergence for women, but not for men, over the 1991-2001 period. As well, although the return to over-education for foreign born men and women rises over that period, there is a narrowing of the gap between the foreign-born and native born only for men, but not for women. We also find that the penalty associated with under-education falls quite substantially for foreign-born men and women relative to their native-born counterparts; yet, by 2001, it is still substantially below that of the native-born. Thus, the benefits of positive selection, which may be responsible for the smaller penalty to under-education for new foreign-born, appear to persist even after 10 years. These findings suggest that convergence in the educational mismatch between the native-born and foreign-born by gender is only partial even after 10-15 years in the country.

From a policy perspective, the news is not all bad; the less-educated foreign-born, who are more likely to be under-educated, actually do better than expected relative to the native-born. This holds for both men and women. On the hand other hand, the persistence of greater penalties for over-education among the foreign-born, especially women, points to the presence of barriers such as blocked occupational mobility resulting from the non-recognition of foreign credentials and discrimination, and perhaps cultural attitudes. The latter might be especially important in the greater gender differences observed for traditional foreign-born such as South Asians and Chinese. Of course, it needs to be recognized that the native-born suffer from greater penalties from under-education. This, combined with the finding that both types of penalties are large in relation to matched return for both groups, suggests that there is a significant aggregate cost from educational mismatch, regardless of nativity status. Thus, although policies that facilitated the recognition and/or the upgrading of foreign credentials, and reduced discrimination on the basis of sex and country-of origin would certainly help the foreign-born, particularly women, what is perhaps needed are policies that facilitate better job matching for men and women, both foreign-born and native-born.

\section{References}

Baker, M., \& Benjamin, D. (1994). The performance of foreign-born in the Canadian labour market. Journal of Labor Economics, 12(3), 369-405. http://dx.doi.org/10.1086/298349

Barrett, A., \& Duffy, D. (2008). Are Ireland's foreign-born integrating into its labor market? International Migration Review, 42(3), 597-619. http://dx.doi.org/10.1111/j.1747-7379.2008.00139.x

Chiswick, Barry R. (1978). The effect of Americanization on the earnings of foreign-born men. Journal of Political Economy, 86(5), 897-921. http://www.jstor.org/stable/1828415 
Chiswick, Barry R. (1999). Are foreign-born favorably self-selected? American Economic Review, 89(2), 181-185. http://dx.doi.org/10.1257/aer.89.2.181

Chiswick, Barry R., \& Miller Paul W. (2008). Why is the payoff to schooling smaller for foreign-born? Labour Economics, 15(6), 1317-1340. http://dx.doi.org/10.1016/j.labeco.2008.01.001

Chiswick, Barry R., \& Miller, Paul W. (2009c). Educational mismatch: are high-skilled Immigrants really working at high-skilled jobs and the price they pay if they are aren't? (Discussion Paper 4280). Institute for the Study of Labour (IZA): Bonn. Retrieved from http://hdl.handle.net/10419/35828

Chiswick, Barry R., \& Miller, Paul W. (2009d). ORU analyses of immigrant earnings in Australia, with international comparisons. (Discussion Paper 4422). Institute for the Study of Labour (IZA): Bonn. Retrieved from http://hdl.handle.net/10419/35984

Chiswick, Barry R., \& Miller, Paul. W. (2009b). The international transferability of foreignborn human capital. Economics of Education Review, 12, 162-169. http://dx.doi.org/10.1016/j.econedurev.2008.07.002

Chiswick, Barry. R., \& Miller, Paul W. (2009a). An explanation for the lower payoff to schooling for foreign-born in the Canadian labour market (Discussion Paper 4448). Institute for the Study of Labour (IZA): Bonn. Retrieved from http://hdl.handle.net/10419/35987

Dell'Aringa, C., \& Pagani, L. (2010), Labour market assimilation and overeducation: the case of foreign-born workers in Italy (Working Paper 178), Department of Economics, University of Milano-Biccoca. Retrieved from http://dipeco.economia.unimib.it/repec/pdf/mibwpaper178.pdf

Fernandez, C., \& Ortega, C. (2008). Labor market assimilation of foreign-born in Spain: employment at the expense of bad job-matches? Spanish Economic Review, 10, 83-107. http://dx.doi.org/10.1007/s10108-007-9032-4.

Ferrer, Ana \& Riddell, Craig W. (2008), Education, credentials, and foreign-born earnings. Canadian Journal of Economics, 41(1), 186-216. http://dx.doi.org/10.1111/j.1365-2966.2008.00460.x

Gneezy, Uri, Leonard, K.L., \& List, J.H. (2009). Gender differences in competition: evidence from a matrilineal and a patriarchal society, Econometrica, 77(5), 1637-1664. http://dx.doi.org/10.3982/ECTA6690

Green, C., Kler, P., \& Leeves, G. (2008). Foreign-born overeducation: evidence from recent arrivals to Australia. Economics of Education Review, 26, 420-432. http://dx.doi.org/10.1016/j.econedurev.2006.02.005

Groot, W., \& Maassen van den Brink, H. (2000). Overeducation in the labor market: a meta analysis, Economics of Education Review, 19, 149-158. http://dx.doi.org/10.1016/S0272-7757(99)00057-6 


\section{Macrothink}

Hartog, J. (2000). Over-education and earnings: where are we, where should we go? Economics of Education Review, 19(2), 131-147. http://dx.doi.org/10.1016/S0272-7757(99)00050-3

International Labour Office (2004). Breaking through the glass ceiling: women in management, International Labour Office: Geneva. Retrieved from http://ilo.org/dyn/gender/docs/RES/292/f267981337

Kleinjans, K. J. (2009). Do gender differences in preferences for competition matter for occupational expectations? Journal of Economic Psychology, 30(5), 701-710. http://dx.doi.org/10.1016/j.joep.2009.03.006

McGuinness, S. (2006). Overeducation in the labour market. Journal of Economic Surveys, 20(3), 387- 418. http://dx.doi.org/10.1111/j.0950-0804.2006.00284.x

O'Connor, V. J. (2001). Women and men in senior management-a "different needs" hypothesis. Women in Management Review, 16(8), 400-404. http://dx.doi.org/10.1108/EUM0000000006291

Poot, Jacques, \& Stillman, S. (2010). The importance of heterogeneity when examining Foreign-born education-occupation mismatch: evidence from New Zealand. (Discussion paper 5211). Institute for the Study of Labour (IZA): Bonn. Retrieved from http://hdl.handle.net/10419/46061

Ramos, Surinach, R., J \& Artis, M. (2009). Regional economic growth and human capital: The role of overeducation (Discussion Paper 4453), Institute for the Study of Labour (IZA): Bonn. Retrieved from http://hdl.handle.net/10419/36034

Wald, S., \& Fang, T. (2008). Over-educated foreign-born in the Canadian labour market: evidence from the workplace and employee survey. Canadian Public Policy, 34(4), 457-479. http://dx.doi.org/10.3138/cpp.34.4.457

\section{Copyright Disclaimer}

Copyright reserved by the author(s).

This article is an open-access article distributed under the terms and conditions of the Creative Commons Attribution license (http://creativecommons.org/licenses/by/3.0/). 